\title{
Mutagenic, Genotoxic and Immunomodulatory effects of Hydroxychloroquine and Chloroquine: a review to evaluate its potential to use as a prophylactic drug against COVID-19
}

\author{
Allan Giri', Ankita Das ${ }^{2}$, Ajoy K. Sarkar ${ }^{3}$ and Ashok K. Giri ${ }^{4^{*}}$
}

\begin{abstract}
Hydroxychloroquine (HCQ) and Chloroquine (CQ) are two anti-malarial drugs that are now being extensively used by front-line healthcare workers and other common people as a prophylactic drug against the Corona Virus Disease - 19 (COVID-19) in India and as well as in many parts of the world. While only a few in vitro studies have pointed to some efficacy of these drugs as a prophylactic against COVID-19, to date, there are no clinical studies that have established any clinical efficacy of these drugs as a prophylactic. These drugs are commonly used for the treatment of Rheumatoid Arthritis (RA) and Systemic Lupus Erythematosus (SLE) because of its immunomodulatory effects. Previously, we have evaluated the genetic toxicology of different drugs and chemicals including antimalarial drug CQ both in vitro and in vivo. Thus, we recognize the need to critically review the mutagenic, genotoxic, and immunomodulatory effects of these drugs, to find out whether it is safe to use as a prophylactic drug against COVID-19. Existing literature suggests that CQ can induce mutagenic and genotoxic effects in multiple test systems and both the drugs have immunomodulatory effects. There was no data available to evaluate the mutagenicity and genotoxicity for HCQ. However, during metabolism about $60 \%$ of both the drugs remain unchanged and about $40 \%$ of the drugs are metabolized into two metabolites, desethylchloroquine and bisdesethylchloroquine by the action of the cytochrome P450 (CYP) enzymes in the liver. Both HCQ and CQ are immunomodulatory drugs and have the potential to suppress normal immune system activation. In this review, we have elucidated the mechanism of immunomodulation by both HCQ and CQ and highlighted the mutagenic and genotoxic effects from the available literature. This article is written with the sole objective that the reader will be able to recognize the adverse effects of these drugs when consumed by healthy individuals as a prophylactic. Current literature indicates that healthy individuals should refrain from the use of these drugs until further investigation.
\end{abstract}

Keywords: Hydroxychloroquine, Chloroquine, Mutagenicity, Genotoxicity, Immunomodulation, prophylactic use, COVID-19

\footnotetext{
*Correspondence: akgiri@iicb.res.in; akgiri15@yahoo.com

${ }^{4}$ Molecular Genetics Division, CSIR-Indian Institute of Chemical Biology, 4 Raja

S. C. Mullick Road, Kolkata 700032, India

Full list of author information is available at the end of the article
}

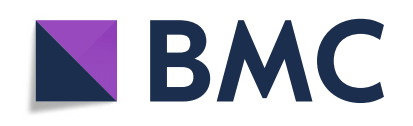

(0) The Author(s). 2020 Open Access This article is licensed under a Creative Commons Attribution 4.0 International License, which permits use, sharing, adaptation, distribution and reproduction in any medium or format, as long as you give appropriate credit to the original author(s) and the source, provide a link to the Creative Commons licence, and indicate if changes were made. The images or other third party material in this article are included in the article's Creative Commons. licence, unless indicated otherwise in a credit line to the material. If material is not included in the article's Creative Commons licence and your intended use is not permitted by statutory regulation or exceeds the permitted use, you will need to obtain permission directly from the copyright holder. To view a copy of this licence, visit http://creativecommons.org/licenses/by/4.0/. The Creative Commons Public Domain Dedication waiver (http://creativecommons.org/publicdomain/zero/1.0/) applies to the data made available in this article, unless otherwise stated in a credit line to the data. 


\section{Background}

The novel Severe Acute Respiratory Syndrome Corona Virus 2 (COVID-19) pandemic has now become a nightmare throughout the world. This pandemic has caused serious health crisis not only among the poor nations but also across the world's advanced countries. Researches all across the globe are trying to find an effective drug that would show promising results to prevent or to treat and control the COVID- 19. Recently, scientists have pointed out that the novel COVID-19 was transmissible in aerosol [1]. Thus, it puts the healthcare workers at risk who works in close proximity with COVID-19 patients. This demanded the need for a prophylactic drug against COVID-19 amongst healthcare workers.

Hydroxychloroquine (HCQ) and Chloroquine (CQ) are two antimalarial drugs that remain the universally accepted drugs for the treatment of Rheumatoid arthritis and Systemic Lupus Erythematosus [2-5]. These two drugs have shown some results in inhibiting the novel COVID-19 in vitro $[6,7]$. A recent study demonstrated that certain cell types when treated with HCQ or CQ and then exposed to the novel COVID-19 strain, presented antiviral activity and that HCQ was more potent than CQ [8]. On the other hand, another in vitro study found out that CQ was potent than HCQ at all four different multiplicities of infection to act as antiviral when exposed to COVID-19 post-incubation with these drugs [7]. Additionally, CQ was able to act as anti-viral both pre and post-infection against the COVID-19 in vitro [6]. These findings may have led to the proposal and optimistic use of $\mathrm{HCQ}$ and $\mathrm{CQ}$ as prophylactics.

Yet historically, we have seen that in vitro studies don't always translate in vivo or human subjects. For instance, despite the strong evidence of CQ as a prophylactic against influenza $A$ and $B$ in vitro, $C Q$ was not effective to prevent either influenza A or B in the human subjects [9]. Rather, dizziness, nausea, and diarrhea were more common in the CQ group compared to the control (placebo) group. Another study showed that Ebola virus replication was successfully inhibited in vitro by $C Q$, however, it failed in guinea pig models in vivo [10]. Yet another study showed CQ enhanced Chikungunya virus replication in vivo when in fact CQ had been shown to have an effective inhibitory effect in vitro [11]. Thus, to date, with the lack of any controlled clinical trials, the clinical effectiveness of these drugs as prophylactics against COVID-19 in vivo remains unanswered.

Like any other drugs, these drugs also comes with certain risks. So, we mustn't overlook the toxicological risks while making a rational decision of using these drugs as prophylactics. Previously, we have extensively reviewed and evaluated the genetic toxicology of antimalarial, analgesics, antipyretic drugs including CQ [12-14]. CQ and HCQ are both water-soluble drugs that are absorbed rapidly in the gut and have a long elimination half-life in the plasma of 900 and $1300 \mathrm{~h}$ respectively [15]. Multiple authors, including us, have reported in vitro and in vivo evidence of CQ-induced genotoxicity in the mammalian system. These drugs also possess immunomodulatory roles that have the potential to suppress the activation of the immune system in healthy individuals [16-18]. Considering the current situation, there is an urgent need for clinical studies to evaluate the clinical efficacy of HCQ and CQ as a prophylactic drug against COVID-19. We have not included the long-term side effects of these drugs since it is unlikely that prophylactic use of these drugs would be for a long time. Here in this review, we mainly aim to critically review and discuss the mutagenic, genotoxic, and immunomodulatory aspects of HCQ and CQ using the available literature.

\section{Review}

\section{Mutagenic and genotoxic effect}

Table 1 summarizes the mutagenic, genotoxic and carcinogenic effects of CQ in multiple test systems. It is interesting to note that there is almost no report on the mutagenic and genotoxic effects of HCQ both in vitro and in vivo. However, both HCQ and CQ have a very similar, flat aromatic core structure with a basic side chain. The only difference is the presence of an additional hydroxyl $(-\mathrm{OH})$ group in HCQ. During metabolism, about $60 \%$ of both the drugs remain unchanged and about $40 \%$ of both the drugs are metabolized into two common metabolites desethylchloroquine and bisdesethylchloroquine by the action of the cytochrome P450 (CYP) enzymes in the liver [46]. Despite CQ being recognized as more toxic than HCQ, the tissue and plasma distribution of these two drugs were reported to be nearly identical when administered in equivalent dosage in humans [46]. Figure 1 shows the comparison of structures and metabolism of HCQ and CQ as described by Schrezenmeier and Dorner [47]. HCQ produces two first-stage metabolites instead of one. One being Desthylhyoxychloroquine and the other Desthylchloroquine. Desthylchloroquine is also the firststage metabolite product of Chloroquine. Both the firststage metabolites are further metabolized to a common product, Bisdesthylchloroquine [47].

While many authors have reported CQ to induce mutagenic effects in bacterial systems [20-22, 24, 27-30, 32], few authors had found weak or no mutagenic associations in certain bacterial strains [14, 23, 25, 28, 31-33]. Positive mutagenic effects (either weak positive or positive) reported by several authors showed that CQ is capable of inducing mutation in the Salmonella strains TA97, TA97a, TA153 and TA1538, which are used to detects the frameshift mutations. During the mutagenicity assay, most studies did not find any significant differences in the revertant numbers either with or without metabolic activation 
Table 1 Mutagenic, genotoxic and carcinogenic effects of chloroquine in multiple test systems

\begin{tabular}{|c|c|c|c|c|}
\hline Test system & Dose Used & Endpoints & Effects & References \\
\hline \multicolumn{5}{|l|}{ Bacterial strains } \\
\hline Escherichia coli & $1 \times 10^{-3} \mathrm{M}$ & DR & + & [19] \\
\hline Salmonella typhimurium TA1537 & 100 and $250 \mu \mathrm{g} / \mathrm{ml}$ & MU & + & [20] \\
\hline Escherichia coli B/r & $50 \mu \mathrm{g} / \mathrm{ml}$ & MU & + & [21] \\
\hline Salmonella typhimurium TA1537 & 10-10,000 $\mu \mathrm{g} /$ plate & MU & + & [22] \\
\hline (Salmonella typhimurium TA1537, TA1538, TA98 and TA100 & 5-5000 $\mu \mathrm{g} /$ plate & MU & - & [23] \\
\hline Escherichia coli & $300-500 \mu \mathrm{g} / \mathrm{ml}$ & DR & + & [24] \\
\hline Salmonella typhimurium TA1537 and TA97a & $312-500 \mu \mathrm{gg} /$ plate & MU & _- & [25] \\
\hline Drosophila melanogaster & $3-10 \mathrm{mM}$ & SRL & + & [26] \\
\hline Salmonella typhimurium TA100, TA1537, TA1538 & 5-10 $\mu \mathrm{g} /$ plate & MU & + & [27] \\
\hline Salmonella typhimurium TA97 Escherichia coli EE97 and EE102 & $25-200 \mu \mathrm{g} / \mathrm{ml}$ & MU & + & [28] \\
\hline Salmonella typhimurium, TA102 E. coli strains WP2, WP2hcr, WP6 and WP67 & $25-200 \mu \mathrm{g} / \mathrm{ml}$ & MU & - & [28] \\
\hline Salmonella typhimurium TA97 Escherichia coli DG1669 & $25-500 \mu \mathrm{g} /$ plate & MU & + & [29] \\
\hline Salmonella typhimurium TA1537, TA1538, TA98 and TA100 & $100-600 \mu \mathrm{g} / \mathrm{ml}$ & MU & + & [30] \\
\hline Salmonella typhimurium TA1977, TA1978 & $100-600 \mu \mathrm{g} / \mathrm{ml}$ & MU & - & [30] \\
\hline Salmonella typhimurium TA97a and TA100, TA104 & $0.1-10,000 \mu \mathrm{g} /$ plate & MU & \pm & [14] \\
\hline Salmonella typhimurium TA98 & $192.5-6160 \mu \mathrm{g} /$ plate & MU & \pm & [31] \\
\hline Salmonella typhimurium TA98, TA100, TA97, TA1537 & $\begin{array}{l}0-10,000 \mu \mathrm{g} / \text { plate; } \\
250 \mu \mathrm{g} / \text { plate; } 200 \mu \mathrm{g} / \mathrm{ml}\end{array}$ & MU & + & [32] \\
\hline Salmonella typhimurium TA1535, TA1977, TA102, TA104 & $\begin{array}{l}10,000 \mu \mathrm{g} / \text { plate; } 600 \mu \mathrm{g} / \text { plate } \\
5000 \mu \mathrm{g} / \text { plate }\end{array}$ & MU & - & [32] \\
\hline Salmonella typhimurium TA100 & 10-5000 $\mu \mathrm{g} /$ plate & MU & \pm & [33] \\
\hline \multicolumn{5}{|l|}{ In vitro studies on mammalian systems } \\
\hline Rat liver cells & $0.2 \mathrm{mM}$ & DR & + & [34] \\
\hline Human lymphocytes & $15-100 \mu \mathrm{g} / \mathrm{ml}$ & CA & + & [35] \\
\hline Chinese hamster ovary $(\mathrm{CHO})$ cells & $5-100 \mu \mathrm{M}$ & $\begin{array}{l}\text { MN } \\
\text { SCE }\end{array}$ & $\begin{array}{l}+ \\
+\end{array}$ & [36] \\
\hline Chinese hamster lung fibroblast (V79) \& Rat hepatocyte cells (H4) & $0.001-10 \mu \mathrm{g} / \mathrm{ml}$ & SCE & + & [27] \\
\hline Chinese hamster lung fibroblast V79 cells & $1-340 \mu \mathrm{M}$ & MN & + & [37] \\
\hline Rat liver cells & Full text not available & DD & + & [38] \\
\hline Rat liver cells & $0-1000 \mu \mathrm{M}$ & DD & + & [39] \\
\hline \multicolumn{5}{|l|}{ In vivo studies in multiple test systems } \\
\hline Rheumatoid patients & $250 \mathrm{mg} /$ day for 6 years & CA & + & [40] \\
\hline Patients with aplastic anemia & $\begin{array}{l}\text { Data not available. } \\
\text { Patients took CQ for several months }\end{array}$ & $\mathrm{CO}^{\mathrm{a}}$ & + & [41] \\
\hline Mouse bone marrow cells & $12.5-100 \mathrm{mg} / \mathrm{kg}$ in single i.p. dose & $\begin{array}{l}\text { CA } \\
\text { SCE }\end{array}$ & $\begin{array}{l}+ \\
+\end{array}$ & [14] \\
\hline Wistar rats & $\begin{array}{l}20 \mathrm{mg} / \mathrm{kg} \text { orally thrice a week continued } \\
\text { up to } 400 \text { days. }\end{array}$ & $\mathrm{CO}^{\mathrm{b}}$ & + & [42] \\
\hline Mouse bone marrow cells & $\begin{array}{l}10-30 \mathrm{mg} / \mathrm{kg} \text { in single i.p. dose and one } \\
\text { sub acute i.p.dose } 10 \mathrm{mg} \text { daily for } 3 \text { days. }\end{array}$ & $\begin{array}{l}\text { MN } \\
\text { CA }\end{array}$ & $\begin{array}{l}+ \\
+\end{array}$ & [43] \\
\hline Egyptian Toad Bufo & $\begin{array}{l}\text { Toads weighing } 50 \mathrm{~g} \text { gavaged } 0.5 \mathrm{mg} \text { and } \\
\text { after } 6 \mathrm{~h} 0.1 \mathrm{mg} \text { and then } 0.1 \mathrm{mg} \text { daily for } \\
3 \text { days }\end{array}$ & $\mathrm{CO}$ & + & [44] \\
\hline Male Wistar rats & $\begin{array}{l}10 \mathrm{mg} / \mathrm{kg} \text { i.p. for once a day for } 7,14 \text { and } \\
21 \text { days }\end{array}$ & $\mathrm{DD}$ & + & [45] \\
\hline
\end{tabular}

+: Positive effect, \pm : Weakly positive effect, - : Negative (non mutagenic) effect,

MU: Mutagenicity assay, CA: Chromosomal aberrations, SCE: Sister-Chromatid Exchange,

SRL: Sex linked recessive lethals. DD: DNA Damage, DR: Inhibition of DNA Repair,

MN: Micronuclei formation, CO: Carcinogenicity (Lymphosarcomas),

$\mathrm{CO}^{\mathrm{a}}$ : Carcinogenicity (Myeloblastic leukaemia), $\mathrm{CO}^{\mathrm{b}}$ : Co-Carcinogenic effects 


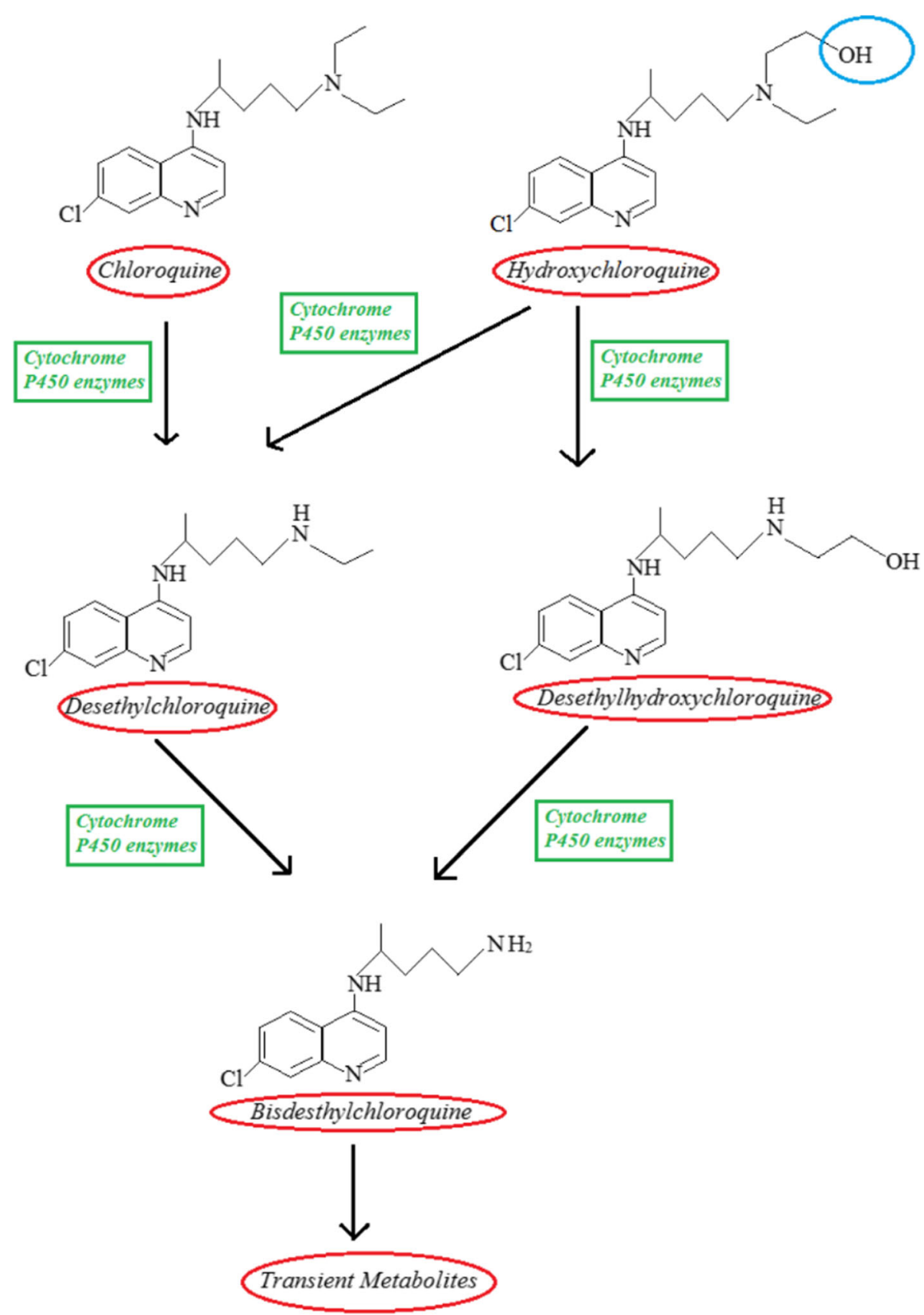

Fig. 1 Comparison of structures and metabolism of Hydroxychloroquine (HCQ) and Chloroquine (CQ): Both HCQ and CQ have a very similar, basic, and a flat aromatic structure. The only difference is the presence of an additional hydroxyl (-OH) group in $\mathrm{HCQ}$ as highlighted by the blue oval in the representation. Dealkylation of HCQ and CQ are mediated by Cytochrome P450 enzymes in the liver. HCQ produces two first-stage metabolites instead of just one. The two metabolites are Desthylhydroxychloroquine and Desthylchloroquine. Desthylchloroquine is also the first-stage metabolite product of $C Q$. Both the first-stage metabolites are further metabolized to a common product, Bisdesthylchloroquine

system (S9). This indicates that CQ is a direct-acting mutagen. In addition to Salmonella strains, CQ showed mutagenic effects in Escherichia coli EE97, EE102, DG1669 strains, and WP2, WP2hcr, WP6 and WP67 strains $[21,28-30]$. CQ also can interact with DNA and produce an intercalated complex that may induced frameshift mutation by shifting the reading frame $[48,49]$. This also indicates it's DNA damage and inhibition of DNA repair potentials reported by several authors $[19,34,38,39$, 45]. CQ is further reported to induce sex-linked recessive 
lethal mutation in Drosophila melanogaster [26]. These results indicate the mutagenic potentials of CQ in bacterial systems.

In a broad genotoxic review on several antimalarial drugs, cumulative pieces of evidence pointed out that CQ is also a genotoxic drug [50]. Our study on CQ has demonstrated genotoxic effect as measured by chromosomal aberrations (CA), sister chromatid exchange (SCE), and micronuclei (MN) formations in vivo in mice [14]. These results are in agreement with several other authors who have reported CQ to be a genotoxic drug in both in vitro and in vivo systems [35-37, 40,43]. CQ has also been reported to induce oxidative stress in animal models [51]. For instance, when CQ administered intraperitoneally in rats, it induced DNA breaks in the kidney within 1 to 2 weeks and in the liver within 2 to 3 weeks [45]. Chromosomal Aberrations (CA) have also been long considered to be a predictor for cancer. Rossner et al., [52] reported a strong association between increased frequencies of CA in cells and an increased risk for cancer using a cohort of 11,834 subjects. CA along with other genotoxic effects like SCE and $\mathrm{MN}$ as reported here, suggests that long-term use of CQ can induce significant chromosomal damages which may lead to an increased risk of cancer in humans.

$\mathrm{CQ}$ is not considered carcinogenic due to inadequate evidence pointing to carcinogenicity in humans. Yet, a well-controlled study by El-Mofty et al., [44] in Egyptian toad showed that separately CQ and primaquine can induced tumor formation in 14 and $19 \%$ of the toads respectively. They further showed that $\mathrm{CQ}$ and primaquine when used together the incidence of tumor rose to $23.5 \%$ [44]. This type of co-tumorigenic effect of CQ was also observed in another study by Reyes et al., [42] where CQ promoted the carcinogenic effect of a drug called ethynitrosourea on ependymal cells of rodents in vivo. The only report of CQ induced Aplasis and leukemia was observed in a patient treated with long term CQ therapy [41]. Brambilla and Martelli, [53] showed that $N$-nitroso compounds, which are capable of inducing genotoxic effects and tumor formation in animal models, can be formed in the gastric environment when CQ is used with nitrite drugs. So, the genotoxiccarcinogenic effect may be induced when nitrite drugs are taken along with amine drugs like CQ and HCQ. Results presented in the Table 1 indicate that CQ is mutagenic and genotoxic drug in both bacterial systems, and in vitro and in vivo on mammalian systems.

\section{Immunomodulatory effects}

Table 2 summarizes the available reports on the immunomodulatory aspects of HCQ and CQ in multiple test systems. Both HCQ and CQ has been reported to inhibit the activation of the immune system in many ways.
Lysosomotropic drugs (like HCQ and CQ) can accumulate inside lysosomes and being basic they can increase the $\mathrm{pH}$ inside the lysosomes and prevent its normal functions [63, 64]. These drugs can also cause lysosomal membrane destabilization and thus the release of lysosomal contents and enzymes inside the cells [63]. Lysosomes have an essential role in the exogenous (lysosomal) pathways of antigen presentation and therefore proper lysosome functions are essential for MHC class II antigen processing and presentation. The intervention of HCQ and $C Q$ in the exogenous pathway of antigen presentation has been presented in Fig. 2 [64].

Autophagy is an implied concept in immunity development. Besides the degradation and recycling of endogenous substrates, the process of autophagy is a key mechanism used by cells to tackle intracellular pathogens [65]. HCQ and CQ both can potentially inhibit the normal autophagy processes. Autophagosomes require fusion with the lysosomes to start the process of degradation. The increased pH of lysosomes, due to HCQ and CQ intervention, inhibits the maturation of the autolysosome. The inhibition of autophagy has been further linked to the induction of apoptosis of memory T-cells, which is the basis of the mechanism of immunomodulation by these drugs in several autoimmune diseases $[59,66]$. Mechanism of the inhibition of autophagy by HCQ and CQ which triggers apoptosis has been presented in Fig. 3 [59]. HCQ can further block endosomal activation of NADPH oxidase (NOX2) that normally generates the reactive oxygen species and involved in the proinflammatory response of the immune system [60]. With a decreased activity of NADPH oxidase, cells can phagocyte pathogens but can't degrade them inside the phagocytic vesicle.

HCQ can also function as an immunosuppressant by blocking steps in the T-cell activation pathway. HCQ has been shown to inhibit transcription factor NFAT (Nuclear Factor of Activated T-cells) upon T-cell activation in vivo and block expression of co-stimulatory ligand CD154 i.e. CD $40 \mathrm{~L}$, which initiates T-cell dependent Bcell proliferation and antibody formation [17]. The probable mechanism of the interference in the T-cell activation by HCQ has been presented in Fig. 4 [17, 18]. HCQ intervention can further down-regulate the CD69 marker in healthy controls by inhibiting calcium mobilization and dephosphorylation of NFAT [18]. CD69 functions as a costimulatory molecule for $\mathrm{T}$-cell activation and proliferation. The same study showed that B-cell antigen receptor calcium signaling was also reduced by HCQ intervention [18].

Patients on antimalarial drugs like HCQ and CQ have lower levels of IL-6, soluble CD8, and IL-2 receptors which is beneficial for those suffering from autoimmune diseases like SLE and RA [55]. Studies have shown that $\mathrm{CQ}$, at doses that are expected in the serum of treated 


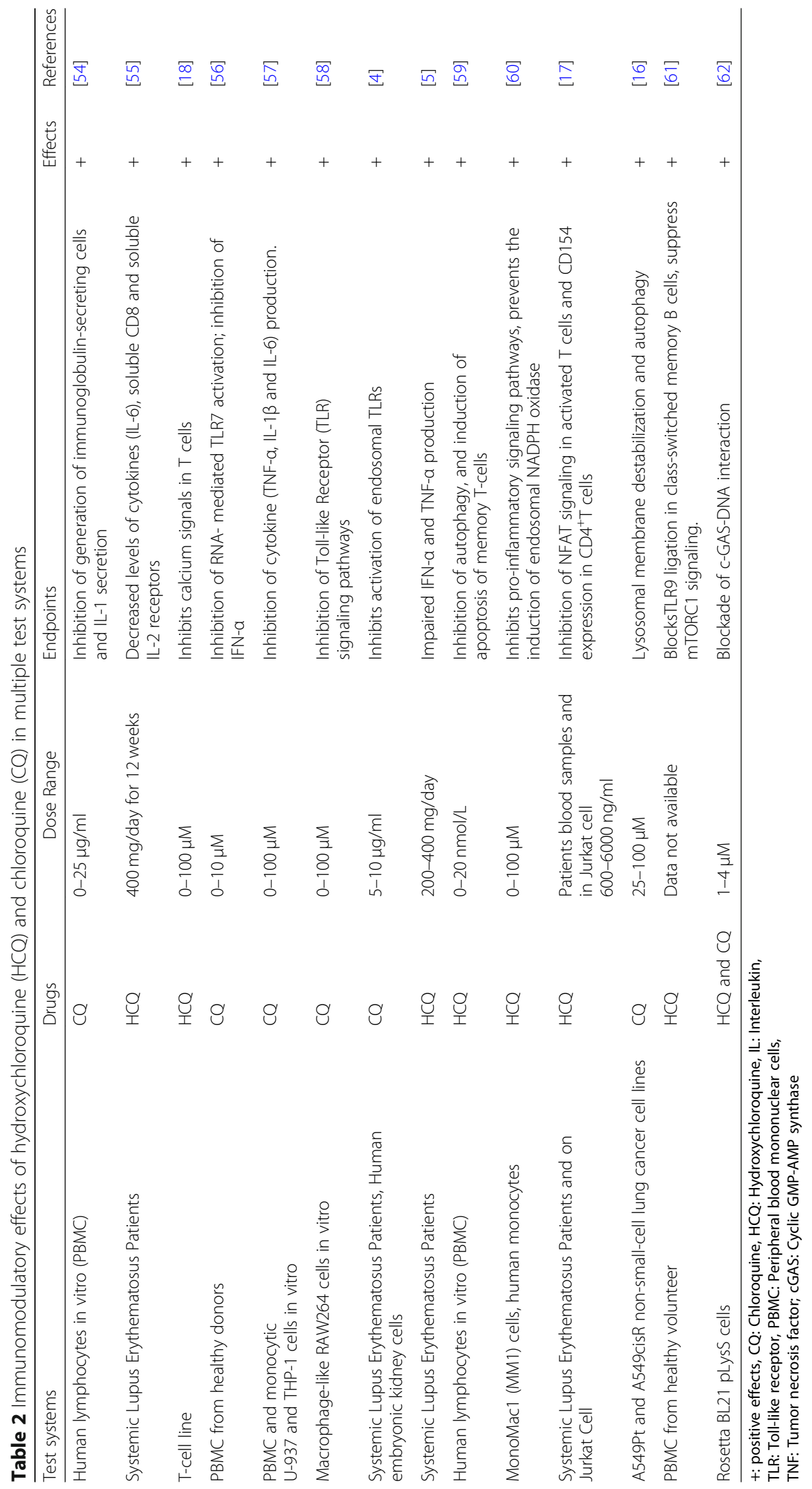




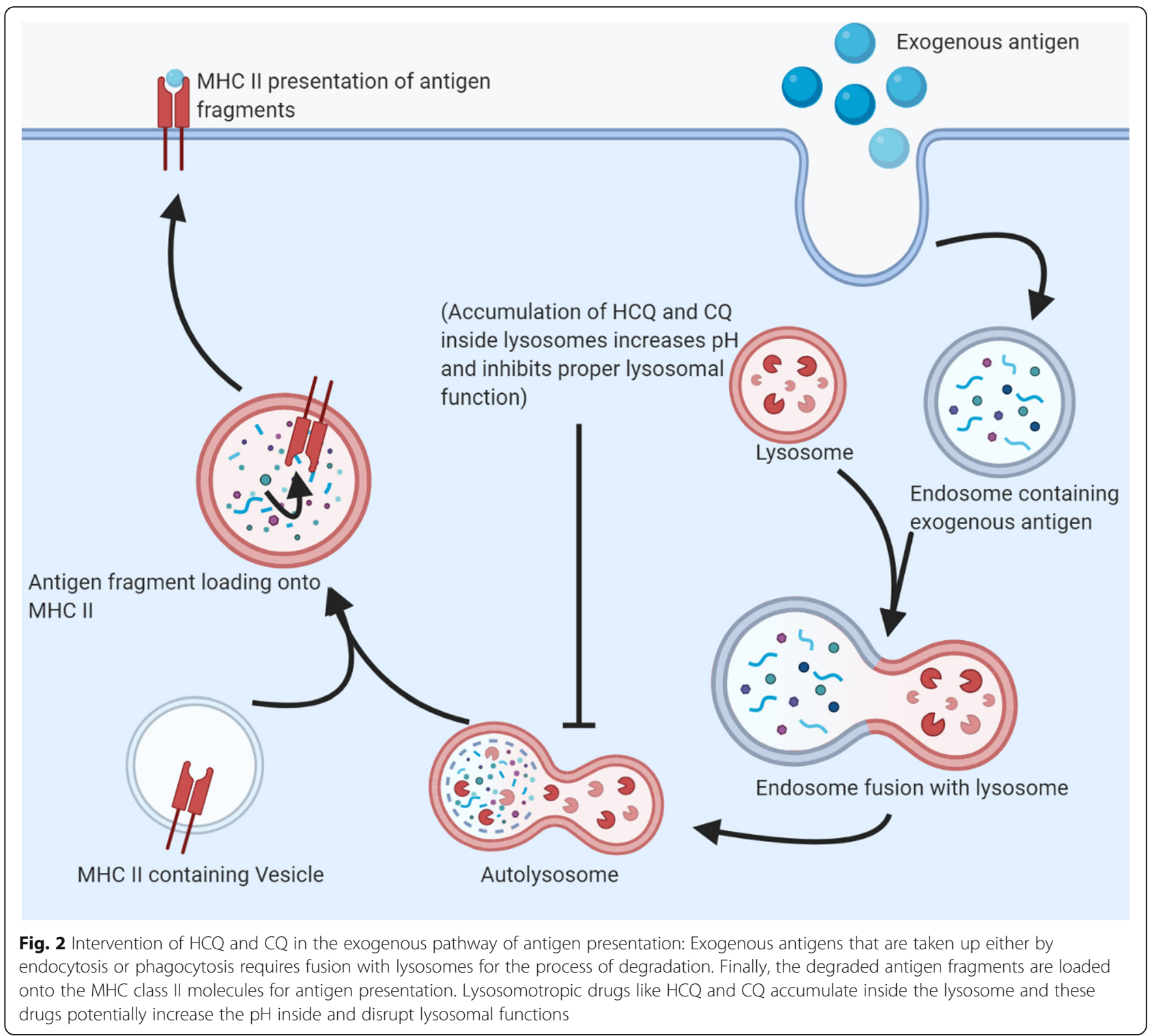

patients, was able to interfere with mitogenic-response of monocytes and this diminished mitogenic response was determined to be irreversible [54]. Furthermore, CQ inhibited the generation of Immunoglobulin-secreting cells by preventing the capacity of monocytes to secrete factors like IL-1 [54]. Normal secretion of TNF- $\alpha$, IL-1b, and IL- 6 by monocytes or macrophages was also inhibited by CQ [57].

HCQ and CQ can potentially inhibit Toll-like receptor (TLR) signaling of TLR7 and TLR9 in Antigen Presenting Cells (APCs) including dendritic cells, macrophages and B-cells. Normally, upon activation of by nucleic acids, endolysosomal TLR7 and TLR9 are cleaved which in turn activates MyD88 and triggers an innate immune response in the downstream cascade. This proteolytic cleavage is inhibited by the changes in the endosomal
$\mathrm{pH}$ as a result of HCQ and CQ interference [58]. The mechanism of the inhibition of endosomal TLR 7 and TLR9 by HCQ and CQ has been presented in Fig. 5 [58]. HCQ and CQ have further been shown to directly bind to nucleic acid, inhibiting TLR-nucleic acid interaction and preventing TLR9 activation [4], and CQ has been shown to inhibit RNA-mediated TLR7 activation [56]. HCQ treatment in vivo caused a significant reduction of the production of INF- $\alpha$ and TNF- $\alpha$ by the plasmacytoid Dendritic cells by suppressing the activation of TLR7 and TLR9 [5]. Innate TLR signaling leads to the production of cytokines such as IL-6, TNF- $\alpha$, and IL-1 that eventually triggers the adaptive immune response. At clinical concentration, HCQ can efficiently block TLR9 ligation and have an inhibitory effect on classswitched memory B-cells [61]. 


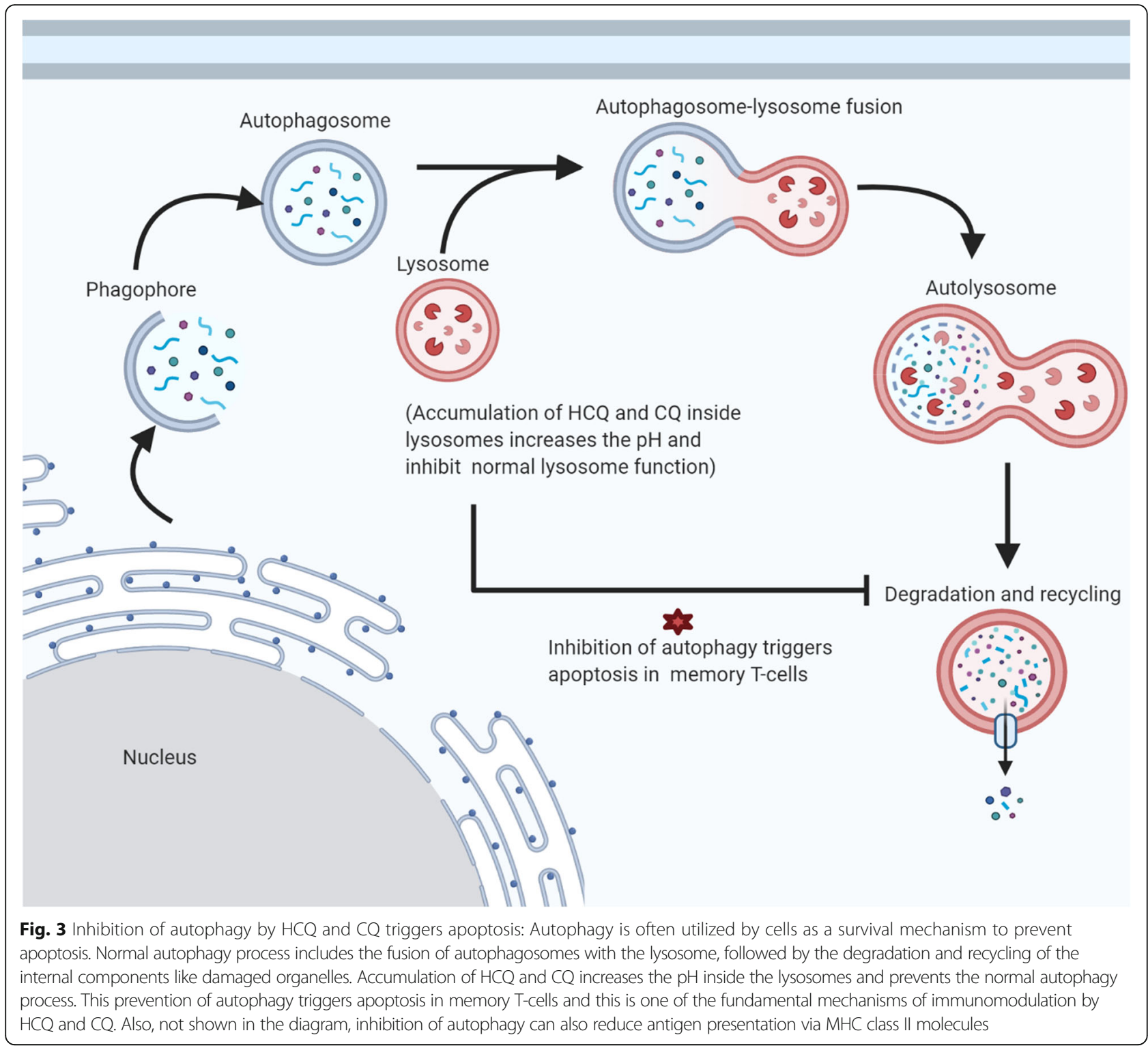

The cGAS-STING is another pathway that is involved in the type I interferon response of innate immunity. Cyclic GMP-AMP synthase (cGAS) is a nucleotidyltransferase that is activated to cGAMP $\left(2^{\prime}, 5^{\prime}\right.$-cyclic GMP-AMP dinucleotide) when dsDNA, usually from a viral or bacterial origin, binds to it. cGMAP then activates an endoplasmic reticulum membrane-associated protein known as the STING (stimulator of interferon genes). Activation of STING leads to the activation of the transcription factor IRF3 and NF-kB, which then can migrate to the nucleus to activate the Type I IFNs and cytokines [67]. Evidence suggests one-way HCQ and CQ can achieve the immunomodulatory effect is because of its ability to suppress the activation of this pathway by inhibiting ligand binding [62] The mechanism of the inhibition of cGAS-STING Pathway by HCQ and CQ has been presented in Fig. 6 [62].
Given all the above mechanisms, it is now clear that these drugs can effectively modulate cellular signaling. Sometimes, this can be helpful but only when used by patients infected with COVID-19. For instance, COVID19 patients have usually higher levels of inflammatory cytokines which ultimately result in collateral damage to the host tissues. The use of HCQ and CQ has been reported to reduce the overproduction of IL-1B, IL-6, and Granulocyte-colony stimulating factor (GM-CSF). The reduction in endosomal acidification as a result of HCQ and CQ accumulation is believed to halt or reduce the disruption of viral particles and thus the release of infectious nucleic acid. The ACE2 receptors of the lungs are required for SARS-CoV2 entry into the host cells. Glycosylation of ACE2 receptors is required for the translocation of ACE2 receptors to the cell membrane. HCQ has 


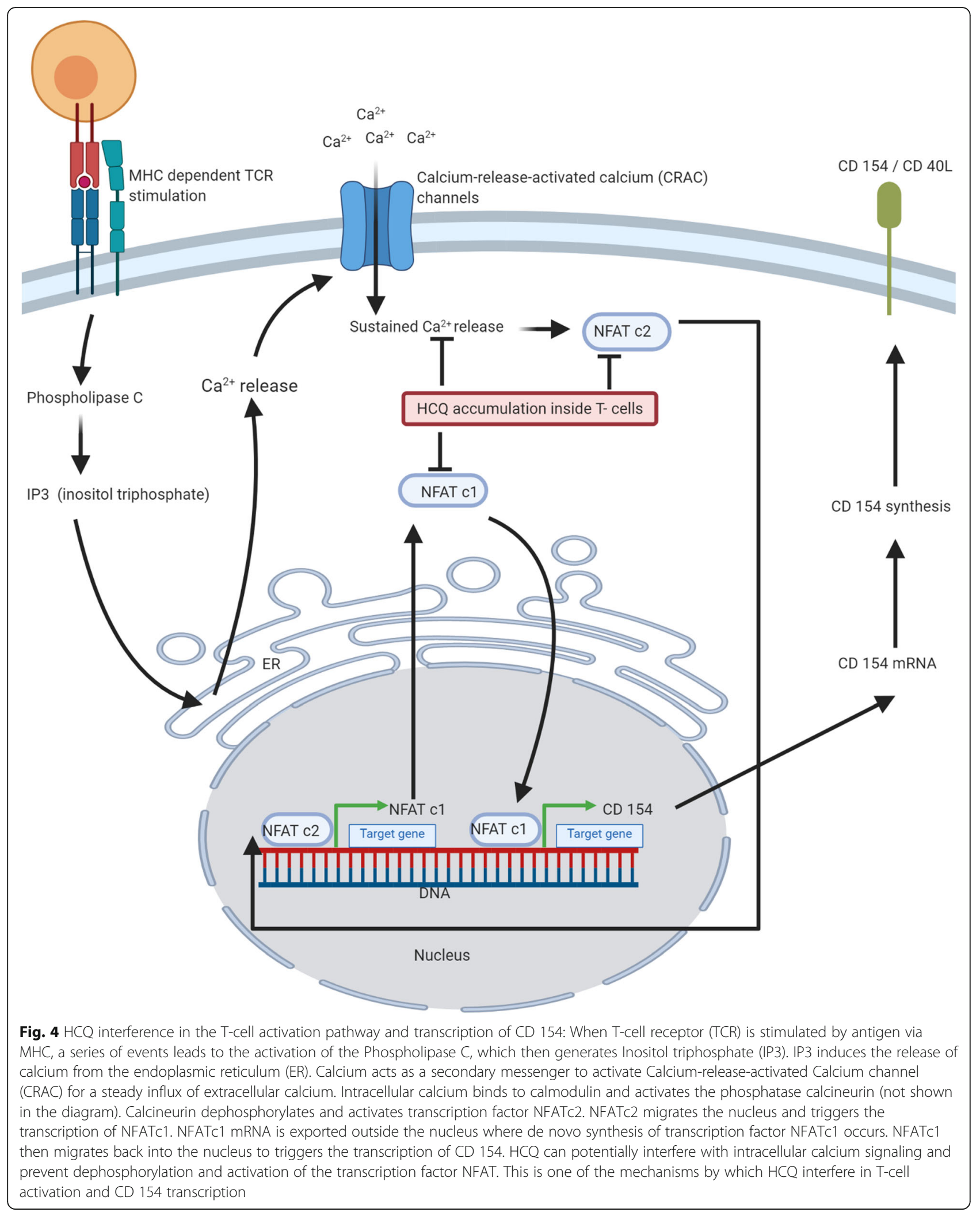




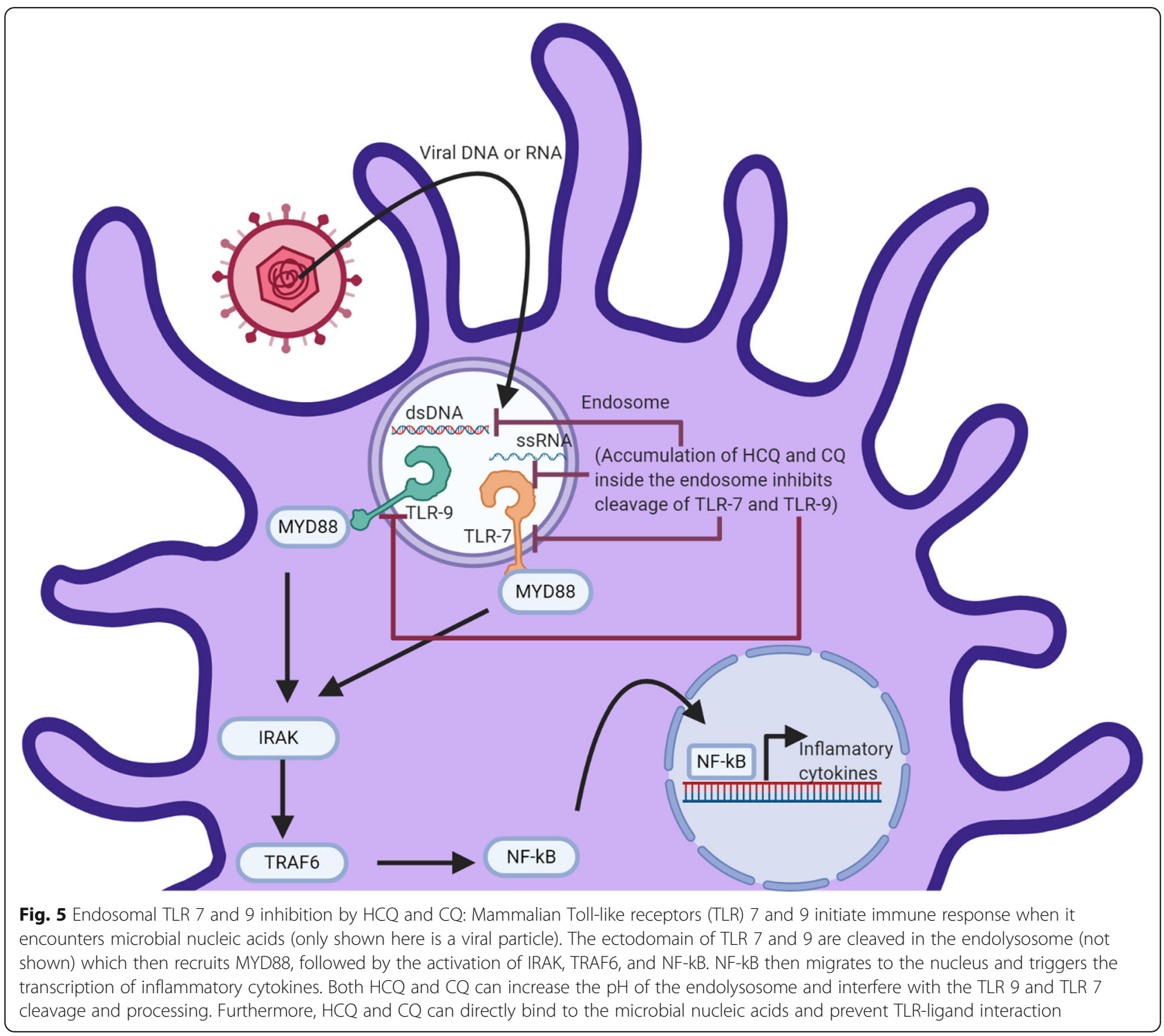

also been shown to reduce this glycosylation step [68]. These studies have together motivated healthcare workers to use these drugs as a prophylactic, postexposure prophylactic, and as a curative drug. Unfortunately, these results were only successful in vitro. As we will discuss later, large clinical trials have found no evidence of the benefit of using these drugs.

\section{Genetic variation leading to a difference in the metabolism of $\mathrm{HCQ}$ and $\mathrm{CQ}$}

It is important to remember the metabolism of these drugs in vivo. Both HCQ and CQ are metabolized in the liver by an enzyme known as cytochrome P450 (CYP) and the gene expression of this enzyme varies between different individuals as a result of the difference in nucleotide polymorphisms [69]. Furthermore, these polymorphisms have been associated with the formation of unstable enzymes and thus a decreased in its activity [70]. Some ethnicities have a complete absence of certain functional CYP enzymes like the CYP 2D6, which is one of the important CYP enzymes that is actively involved in the metabolism of these drugs [69]. An Individual's P450 polymorphisms should be taken into account when considering to prescribe HCQ since there is a clear association between different polymorphisms in CYP 2D6 and the blood concentration of HCQ in SLE patients [69]. These polymorphisms have also been linked to the toxic accumulation of these drugs in the blood of the patients treated with HCQ and CQ [71].

\section{Latest clinical findings}

To date, there is still no evidence that points to any benefit of using these drugs against the COVID-19 as a prophylactic. Moreover, the potentials of these drugs as 


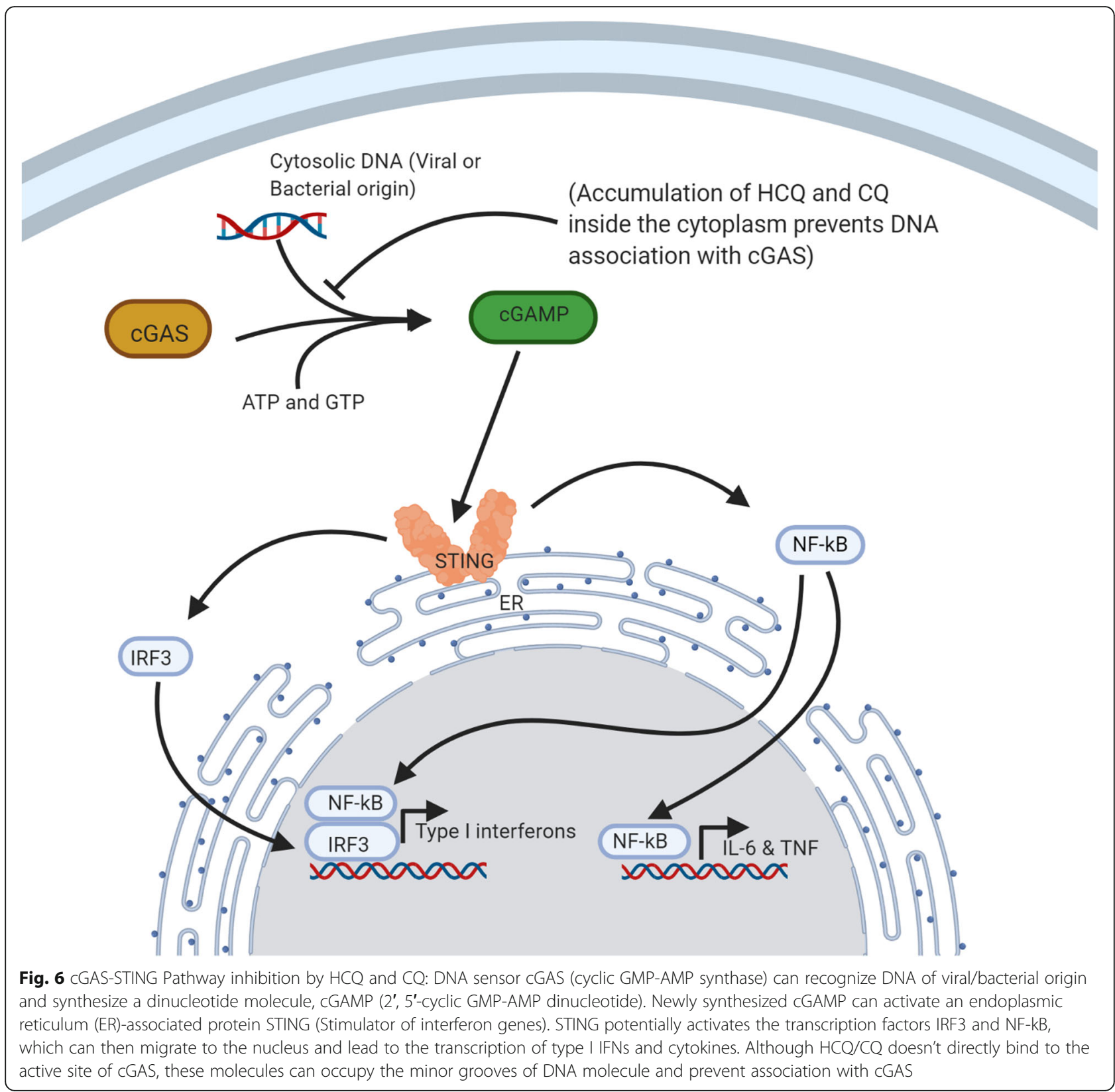

a post-exposure prophylactic or curative drug has also been called into question. Recently, the Food and Drug Administration (FDA) of the United States (US) has revoked their Emergency Use Authorization (EUA) for emergency use of these drugs [72], and the World Health Organization (WHO) [73], along with National Institute of Health (NIH) [74] in the US had also stopped conducting further clinical studies because of sufficient evidence that these drugs provided no benefit.

Initially, a few in vitro evidence and small studies suggested that these medications might be helpful, however, large scale studies have found no such significance. The first clinical evidence of a positive result stems from a small study in China where 100 subjects treated with CQ were found to have a superior benefit over the control group suffering from COVID-19 pneumonia [75]. Another small study in France with only 26 subjects, who received HCQ, showed a significant reduction in the viral load compared to the control group [76]. The time to clinical recovery was also shown to be reduced in those under HCQ treatment in a small randomized trial of just 62 COVID-19 patients [77]. Clearly, the small sample size was a major drawback in these studies. However, larger clinical randomized controlled trial has now been conducted and results have provided us with a different outcome. For instance, a recent study in Brazil 
with 504 confirmed COVID-19 patients, HCQ treatment had no significant benefit over no treatment group [78]. Furthermore, Chloroquine at high doses $(600 \mathrm{mg}$, twice daily) for 10 consecutive days was associated with higher lethality and is now not recommended for critically ill patients [79]. A large randomized clinical study investigating the post-exposure prophylactic role of $\mathrm{HCQ}$ found that a higher dose of HCQ did not prevent infection when treatment was initiated within 4 days after exposure [80]. Another study showed us that in 368 COVID-19 patients those taking HCQ only or HCQ plus Azithromycin had a death rate of 27.8 and $22.1 \%$ respectively when compared to $11.4 \%$ in the no-treatment group [81].

\section{Conclusions}

Most pathogenic microorganisms that infect humans are tackled satisfactorily by the innate and adaptive immune system of our body. Healthy humans have an extraordinary capability to fight off infections caused by pathogenic microorganisms. The activation of innate immunity initiates the first line of defense until the more specific adaptive immunity develops. Existing literature suggests that HCQ and CQ can potentially interfere with both innate and adaptive immune responses in multiple ways. Here in this review, we have highlighted the known pathways where HCQ and CQ can intervene to achieve its immunomodulatory effects and also provided systematic diagrams for a better understanding of the affected pathways.

Furthermore, CQ has been recognized to induce genomic instability by inducing mutagenic, genotoxic, and DNA damages both in vivo and in vitro systems. Most authors, including us, found weak to moderately strong mutagenic effects in different Salmonella strains routinely used for mutagenicity screening of drugs and chemicals. Moreover, almost all authors who worked on genotoxicity assays have reported positive genotoxic effects of CQ in multiple test systems. This indicates that $\mathrm{CQ}$ is a mutagenic and genotoxic drug. However, with a lack of sufficient studies on the genetic toxicology of HCQ both in vitro and in vivo, the mutagenic and genotoxic effects of HCQ remains inconclusive.

Current evidence cumulatively demonstrates that both HCQ and CQ are not effective against the COVID-19 infection either as post-exposure prophylaxis or as a curative drug. No studies on the prophylactic role of these drugs have been evaluated to date. The world is going through tremendous turmoil because of the COVID-19 pandemic. Thus, we do recognize the importance of optimism and the implementation of any advancement in science during this emergency. Thus, the use of these drugs post-infection might be useful, but this discussion is beyond the scope of this review. Here, we are mainly concerned with the use of these drugs by healthy individuals as a prophylactic without any evidence. So, without any clinical or in vivo evidence, current literature suggests that healthy individuals should refrain from the use of these drugs as prophylactics until further investigation.

\section{Abbreviations}

CQ: Chloroquine; HCQ: Hydroxychloroquine; COVID-19: novel Severe Acute Respiratory Syndrome Corona Virus 2; RA: Rheumatoid Arthritis; SLE: Systemic Lupus Erythematosus; CYP: cytochrome P450; S9: Metabolic activation system; +: Positive effect; \pm : Weakly positive effect; -: Negative (non mutagenic) effect; MU: Mutagenicity assay; CA: Chromosomal aberrations; SCE: Sister-Chromatid Exchang; SRL: Sex linked recessive lethals; DD: DNA Damage; DR: Inhibition of DNA Repair; MN: Micronuclei formation;

CO: Carcinogenicity; IL: Interleukin; TLR: Toll-like receptor; PBMC: Peripheral blood mononuclear cells; TNF: Tumor necrosis factor; NFAT: Nuclear Factor of Activated T-cells; cGAS: Cyclic GMP-AMP synthase; STING: Stimulator of interferon genes; ACE2: Angiotensin-converting enzyme 2; GM-

CSF: Granulocyte-colony stimulating factor

\section{Acknowledgments}

The authors are grateful to the Indian National Science Academy to provide the INSA-Senior Scientist position to AKG. Authors are also grateful to the U.S. Federal Government for providing financial support to AG for Graduate Studies in Kansas City University of Medicine and Biosciences and to the Council of Scientific and Industrial Research, New Delhi for providing CSIR-NET (JRF) to AD. Our deep gratitude also to Dr. Pritha Bhattacharjee, Department of Environmental Sciences, University of Calcutta for allowing her student Ms. Ankita Das to work in this review and also for her valuable suggestions. All the Figures in this review have been created with BioRender.com

\section{Authors' contributions}

AG: Planning and designing of the review, literature search, interpretation of results and manuscript writing. All the figures in this manuscript have been prepared by AG. AD: Literature search, preparation of tables and references. AKS: Interpretation of results and manuscript editing. AKG: Concept, planning and designing of the review, literature search, interpretation of results, manuscript editing and supervision of the work. The author(s) read and approved the final manuscript.

\section{Funding}

There is no funding for this work.

Availability of data and materials

Not applicable.

Ethics approval and consent to participate

Not applicable.

\section{Consent for publication}

Not applicabe.

\section{Competing interests}

The authors declares that he have no competing interests.

\section{Author details}

${ }^{1}$ Department of Biomedical Science, Kansas City University of Medicine and Biosciences, Kansas City, MO 64106, USA. ${ }^{2}$ Department of Environmental Sciences, University of Calcutta, Kolkata 700019, India. Intensive Care Unit, Peerless Hospital, B.K. Roy Research Centre, Kolkata 700094, India. ${ }^{4}$ Molecular Genetics Division, CSIR-Indian Institute of Chemical Biology, 4 Raja S. C. Mullick Road, Kolkata 700032, India. 
Received: 28 July 2020 Accepted: 20 August 2020 Published online: 02 September 2020

\section{References}

1. van Doremalen N, Bushmaker T, Morris DH, Holbrook MG, Gamble A, Williamson BN, et al. Aerosol and surface stability of SARS-CoV-2 as compared with SARS-CoV-1. N Engl J Med. 2020;382(16):1564-7.

2. Siddiqui AK, Huberfeld SI, Weidenheim KM, Einberg KR, Efferen LS. Hydroxychloroquine-induced toxic myopathy causing respiratory failure. Chest. 2007;131(2):588-90.

3. Joyce E, Fabre A, Mahon N. Hydroxychloroquine cardiotoxicity presenting as a rapidly evolving biventricular cardiomyopathy: key diagnostic features and literature review. Eur Heart J Acute Cardiovasc Care. 2013;2(1):77-83.

4. Kuznik A, Bencina M, Svajger U, Jeras M, Rozman B, Jerala R. Mechanism of endosomal TLR inhibition by antimalarial drugs and imidazoquinolines. J Immunol. 2011;186(8):4794-804.

5. Sacre K, Criswell LA, McCune JM. Hydroxychloroquine is associated with impaired interferon-alpha and tumor necrosis factor-alpha production by plasmacytoid dendritic cells in systemic lupus erythematosus. Arthritis Res Ther. 2012;14(3):155-65.

6. Wang M, Cao R, Zhang L, Yang X, Liu J, Xu M, Shi Z, Hu Z, Zhong W, Xiao G. Remdesivir and chloroquine effectively inhibit the recently emerged novel coronavirus (2019-nCoV) in vitro. Cell Res. 2020;30(3):269-71.

7. Liu J, Cao R, Xu M, Wang X, Zhang H, Hu H, Li Y, Hu Z, Zhong W, Wang M. Hydroxychloroquine, a less toxic derivative of chloroquine, is effective in inhibiting SARS-CoV-2 infection in vitro. Cell Discov. 2020;6(1):1-4

8. Yao X, Ye F, Zhang M, Cui C, Huang B, Niu P, Liu X, Zhao L, Dong E, Song C, Zhan S. In vitro antiviral activity and projection of optimized dosing design of hydroxychloroquine for the treatment of severe acute respiratory syndrome coronavirus 2 (SARS-CoV-2). Clin Infect Dis. 2020. https://doi.org/ 10.1093/cid/ciaa237.

9. Paton NI, Lee L, Xu Y, Ooi EE, Cheung YB, Archuleta S, Wong G, Smith AW. Chloroquine for influenza prevention: a randomised, double-blind, placebo controlled trial. Lancet Infect Dis. 2011;11(9):677-83.

10. Dowall SD, Bosworth A, Watson R, Bewley K, Taylor I, Rayner E, Hunter L, Pearson GL, Easterbrook J, Pitman R. Chloroquine inhibited Ebola virus replication in vitro but failed to protect against infection and disease in the in vivo Guinea pig model. J Gen Virol. 2015;96(12):3484-92.

11. Roques $P$, Thiberville SD, Dupuis-Maguiraga L, Lum FM, Labadie $K$, Martinon F, Gras G, Lebon P, Ng LF, De Lamballerie X, Le Grand R. Paradoxical effect of chloroquine treatment in enhancing chikungunya virus infection. Viruses. 2018;10(5):268.

12. Giri AK. Genetic toxicology of paracetamol and aspirin - a review. Mutat Res. 1993;296:199-210

13. Giri AK, Adhikari N, Khan KA. Comparative genotoxicity of six salicylic acid derivatives in bone marrow cells of mice. Mutat Res. 1996;370:1-9.

14. Chatterjee T, Mukhopadhyay A, Khan K. A. Giri AK. Comparative mutagenic and genotoxic effects of three antimalarial drugs, chloroquine, primaquine and amodiaquine. Mutagenesis. 1998;13:619-24.

15. Pereira BB. Challenges and cares to promote rational use of chloroquine and hydroxychloroquie in the management of corona virus disease 2019 (COVID-19) pandemic: a timely review. J Toxicol Environ Health. 2020. https://doi.org/10.1080/10937404.2020.1752340.

16. Circu M, Cardelli J, Barr M, O'Byrne K, Mills G, El-Osta H. Modulating lysosomal function through lysosome membrane permeabilization or autophagy suppression restores sensitivity to cisplatin in refractory nonsmall-cell lung cancer cells. PloS One. 2017; 13(5), https://doi.org/10.1371/ journal.pone.0184922.

17. Wu SF, Chang CB, Hsu JM, Lu MC, Lai NS, Li C, Tung CH. Hydroxychloroquine inhibits CD154 expression in CD4+ T lymphocytes of systemic lupus erythematosus through NFAT, but not STAT5, signaling. Arthritis Res Ther. 2017;19(1):183-96.

18. Goldman FD, Gilman AL, Hollenback C, Kato RM. Premack BA, Rawlings DJ. Hydroxychloroquine inhibits calcium signals in T cells: a new mechanism to explain its immunomodulatory properties. Blood. 2000; 95(11):3460-3466.

19. Yielding $K L$, Yielding $L$, Gaudin D. Inhibition by chloroquine of UV repair in E. coli B. Proc Soc Exp Bio I Med. 1970;133(3):999-1001.

20. Schupbach ME. Mutagenicity evaluation of the two antimalarial agents Chloroquine and mefloquine, using a bacterial fluctuation test. Mutat Res. 1979;68(1):41-9.
21. Sideropoulos AS, Specht SM, Jones MT. Feasibility of testing DNA repair inhibitors for mutagenicity by a simple method. Mutat Res. 1980;74(2):95-105.

22. Cortinas de Nava C, Espinosa J, Garcia L, Zapata AM. Martinez, E. Mutagenicity of antiamebic and anthelmintic drugs in the Salmonella typhimurium microsomal test system. Mutat Res. 1983; 117: 79-91.

23. Kadotani S, Arisawa M, Maruyama HB. Mutagenicity examination of several non-steroidal anti-inflammatory drugs in bacterial systems. Mutat Res. 1984; 138:133-6.

24. Sideropoulos AS, Specht SM, Katarincic J, Paszul PJ. The role of chloroquine supplementation in liquid holding recovery and ultraviolet lethality of Escherichia coli strains. Curr Microbiol. 1985;12(5):251-5.

25. O'Donovan MR. The comparative responses of Salmonella typhimurium TA1537 and TA97A to a range of reference mutagens and novel compounds. Mutagenesis. 1990;5:267-74.

26. Xamena N, Creus A, Velazqez A, Marcos R. Testing of chloroquine and quinacnne for mutagenicity in Drosophila melanogaster. Mutat Res. 1985; 158:177-80.

27. Shubber EK, Jacobson-Kram D, Williams JR. Comparison of the Ames assay and the induction of sister chromatid exchanges: results with ten pharmaceuticals and five selected agents. Cell Biol Toxicol. 1986;2(3):379-99.

28. Obaseiki-Ebor EE, Obasi EE. Aspects of chloroquine mutagenicity. Mutat Res. 1986;175(2):51-9.

29. Thomas SM, Silburn KA, MacPhee DG. Frameshift mutagenesis by chloroquine in Escherichia coli and Salmonella typhimurium. Mutat Res. 1987;192(4):233-7.

30. Espinosa-Aguirre JJ, Santos JR. Cortinas de Nava C. influence of the Uvr repair system on the mutagenicity of antiparasitic drugs. Mutat Res. 1989; 222(3):161-6.

31. Riccio ES, Lee PS, Winegar RA, Krogstad DJ, De D, Mirsalis JC. Genetic toxicology testing of the antimalarial drugs Chloroquine and a new analog, AQ-13. Environ Mol Mutagen. 2001;38(1):69-79.

32. U.S. National Library of Medicine-Toxnet, Toxicology Data Network. http://www.toxnet.nlm.nih.gov.

33. Kumar R and Banjare L. Study of the evaluation of mutagenic effects of antimalarial drug chloroquine in Ames Salmonella assay. J drug delivery and therapeutics (JDDT). 2013: 3(6), 70-5.

34. Michael RO, Williams GM. Choloroquine inhibition of repair of DNA damage induced in mammalian cells by methyl methanesulfonate. Mutat Res. 1974; 25(3):391-6

35. Shalumashvili MA, Sigidin IA. Cytogenetic effects of chloroquine in human lymphocyte cultures. Biull Eksp Biol Med. 1976;82(7):879-81.

36. Raj AS, Heddle JA. Simultaneous detection of chromosomal aberrations and sister-chromatid exchanges: experience with DNA intercalating agents. Mutat Res. 1980;78(3):253-60.

37. Snyder RD, Arnone MR. Putative identification of functional interactions between DNA intercalating agents and topoisomerase II using the V79 in vitro micronucleus assay. Mutat Res. 2002:503:21-35.

38. Mohamed MM. Anti-malarial chloroquine stimulate p53-apoptotic pathway in rat hepatocytes. J Egypt Soc Parasitol. 2005;35(1):19-32.

39. Farombi EO. Genotoxicity of chloroquine in rat liver cells: protective role of free radical scavengers. Cell Biol Toxicol. 2006;22(3):159-67.

40. Neill WA. Panayi GS. Duthie JJ, Prescott RJ. Action of chloroquine phosphate in rheumatoid arthritis. II. Chromosome damaging effect. Ann Rheum Dis. 1973;32(6):547-50

41. Nagaratnam N, Chetiyawardana AD, Sudarshini R. Aplasia and leukaemia following chloroquine therapy. Postgrad Med J. 1978;54:108-12.

42. Reyes S, Rembao D, Sotelo J. The antimalarials quinacrine and chloroquine potentiate the transplacental carcinogenic effect of ethylnitrosourea on ependymal cells. Brain Tumor Pathol. 2001;18(2):83-7.

43. Roy LD, Mazumdar M, Giri S. Effects of low dose radiation and vitamin C treatment on Chloroquine-induced genotoxicity in mice. Environ Mol Mutagen. 2008;49(6):488-95.

44. El-Mofty MM, Khudoley W, Sakr SA, Abdel-Gawad HS. The carcinogenicity of some antimalarial drugs using the Egyptian toad bufo regularisas a biological test animal. Nutr Cancer. 1992;18(2):191-8.

45. Giovanella F, Ferreira GK, Pra SDD, Carvalho-Silva M, Gomes LM, Scaini G, Goncalves RC, Michels M, Galant LS, Longaretti LM, Dajori AL. Effects of primaquine and chloroquine on oxidative stress parameters in rats. An Acad Bras Cienc. 2015;87(2):1487-96.

46. Mcchesney EW. Animal toxicity and pharmacokinetics of hydroxychloroquine sulfate. The Am J Medicine. 1983;18:11-8. 
47. Schrezenmeier E, Dorner T. Mechanisms of action of hydroxychloroquine and chloroquine: implications for rheumatology. Nat Rev Rheumatol. 2020 16:155-66.

48. Cohen SN, Yielding KL. Spectrophotometer studies of the interaction of chloroquine with deoxyribonucleic acid. J Biol Chem. 1965;240:3123-31.

49. Waring M. Variation of the supercoils in closed circular DNA by binding of antibiotics and drugs evidence for molecular models involving interaction. J Mol Biol. 1970;54:247-79.

50. Brambilla G, Marttioli F, Robbiano L, Martelli A. Carcinogenicity of antibacterial, antiviral, antimalarial and antifungal drugs. Mutagenesis. 2012; 7:387-413.

51. Magwere T, Naik YS, Hasler JA. Effects of chloroquine treatment on antioxidant enzymes in rat liver and kidney. Free Rad Bio \& Medicine. 1997; 22:321-7.

52. Rossner P, Boffetta P, Ceppi M, Bonassi S, Smerhovsky Z, Landa K, Juzova D, Sram RJ. Chromosomal aberrations in lymphocytes of healthy subjects and risk of cancer. Environ Health Perspect. 2005;113:517-20.

53. Brambilla G, Martelli A. Genotoxic and carcinogenic risk to human of drugnitrite interaction product. Mutat Res. 2007;635:17-52.

54. Salmeron G, Lipsky PE. Immunosuppressive potential of antimalarials. Am J Med. 1983;75(1):19-24.

55. Wallace DJ, Linker-Israeli M, Metzger AL, Stecher VJ. The relevance of antimalarial therapy with regard to thrombosis, hypercholesterolemia and cytokines in SLE. Lupus. 1993;2(1):13-5.

56. Vollmer J, Tluk S, Schmitz C, Hamm S, Jurk M, Forsbach A, Akira S, Kelly KM, Reeves WH, Bauer S, Krieg AM. Immune stimulation mediated by autoantigen binding sites within small nuclear RNAs involves toll-like receptors 7 and 8. J Exp Med. 2005;202(11):1575-85.

57. Jang $\mathrm{CH}$, Choi JH, Byun MS, Jue DM. Chloroquine inhibits production of TNF-alpha, IL-beta and IL-6 from lipopolysaccharide-stimulated human monocytes/macrophages by different modes. Rheumatology. 2006;45(6): 703-10.

58. Ewald SE, Lee BL, Lau L, Wickliffe KE, Shi GP, Chapman HA, Barton GM. The ectodomain of toll-like receptor 9 is cleaved to generate a functional receptor. Nature. 2008;45:658-62.

59. van Loosdregt J, Spreafico R, Rossetti M, Prakken BJ, Lotz M, Albani S. Hydroxychloroquine preferentially induces apoptosis of CD45RO+ effector $T$ cells by inhibiting autophagy: a possible mechanism for therapeutic modulation of T cells. J Allergy Clin Immunol. 2013;131(5):1443-6.

60. Müller-Calleja N, Manukyan D, Canisius A, Strand D, Lackner KJ. Hydroxychloroquine inhibits proinflammatory signalling pathways by targeting endosomal NADPH oxidase. Ann Rheum Dis. 2017;76(5):891-7.

61. Torigoe M, Sakata K, Ishii A, Iwata S, Nakayamada S, Tanaka Y. Hydroxychloroquine efficiently suppresses inflammatory responses of human class-switched memory B cells via toll-like receptor 9 inhibition. Clin Immunol. 2018;195:1-7.

62. An J, Woodward JJ, Sasaki T, Minie M, Elkon KB. Cutting edge: antimalarial drugs inhibit IFN-b production through blockade of cyclic GMP-AMP synthase-DNA interaction. J Immunol. 2015;194:4089-93.

63. Circu M, Cardelli J, Barr M, O'Byrne K, Mills G, El-Osta H. Modulating lysosomal function through lysosome membrane permeabilization or autophagy suppression restores sensitivity to cisplatin in refractory nonsmall-cell lung cancer cells. PloS One. 2017; 12(9): https://doi.org/ 10.1371/ journal.pone.0184922.

64. Fox Rl. Mechanism of action of Hydroxychloroquine as an Antirheumatic drug. Semin Arthritis Rheum. 1993;23:82-91.

65. Levine B, Mizushima N, Virgin HW. Autophagy in immunity and inflammation. Nature. 2011;469:323-35.

66. Boya P, Lez-Polo R-AG, Casares N, Perfettini J-L, Dessen P, Larochette N, Me'tivier D, Meley D, Souquere S, Yoshimori T, Pierron G, Codogno P, Kroemer G. Inhibition of macroautophagy triggers apoptosis. Mol Cell Biol. 2005;25:1025-40.

67. Motwani M, Scott P, Fitzgerald KA. DNA sensing by the CGAS-STING pathway in health and disease. Nat Rev Genet. 2019;20:657-74.

68. Pahan P, Pahan K. Smooth or risky revisit of an old malaria drug for COVID19? J Neuroimmune Pharmacology. 2020. https://doi.org/10.1007/s11481020-09923-W.

69. Neafsey P, Ginsberg G, Hattis D. Sonawane B. Genetic polymorphism in cytochrome P450 2D6 (CYP2D6): population distribution of CYP2D6 activity. J Toxicol environ health. B Crit Rev 2009: 12: 334-361.
70. Lee JY, Vinayagamoorthy N, Han K, Kwok SKJH, Park KS, Jung SH, Park SW, Chung Y-J, Park SH. Association of polymorphisms of cytochrome P450 2D6 with blood hydroxychloroquine levels in patients with systemic lupus erythematosus. Arthritis Rheumatol. 2016:68(1):184-90.

71. Sortica VA, Lindenau JD, Cunha MG. Ohnishi, MDO, Ventura AM R, Ribeirodos-Santos a Kc, Santos SEb, Guimarães L Sp. and Hutz M H. the effect of SNPs in CYP450 in chloroquine/ primaquine plasmodium vivax malaria treatment. Pharmacogenomics. 2016;17:1903-11.

72. U.S. Food \& Drug Administration. Letter revoking EUA for chloroquine phosphate and hydroxychloroquine sulfate. 2020. https://www.fda.gov/ media/138945/download.

73. World Health Organization. Q\&A: Hydroxychloroquine and COVID-19. 2020 https://www.who.int/news-room/q-a-detail/q-a-hydroxychloroquine-andcovid-19.

74. National Institutes of Health. NIH halts clinical trial of Hydroxychloroquine. Study shows treatment does no harm, but provides no benefit. 2020. https://www.nih.gov/news-events/news-releases/nih-halts-clinical-trialhydroxychloroquine.

75. Gao J, Zhenxue T, Yang X. Breakthrough: Chloroquine phosphate has shown apparent efficacy in treatment of COVID-19 associated pneumonia in clinical studies. BioScience Trends. 2020;14:72-3.

76. Gautret $\mathrm{P}$, Lagier J-C, Parola P, Hoang VT, Meddeb L, Mailhe M, Doudier B, Courjon J, et al. Hydroxychloroquine and azithromycin as a treatment of COVID-19: results of an open-label non-randomized clinical trial. Intl J Antimicrobial Agents. 2020;56:105949. https://doi.org/10.1016/j.jiantimicag. 2020.105949.

77. Chen Z, Hul J, Zhang Z, Jiang S, Han S, Yan D, Zhuang R, Hu Ben, Zhang Z. Efficacy of hydroxychloroquine in patients with COVID-19: results of a randomized clinical trial. 2020; MedRxiv, https://doi.org/10.1101/2020.03.22 20040758.

78. Cavalcanti AB, Zampieri FG, Rosa RG, Azevedo LCP, Veiga VC, Avezum A, Damiani LP, Marcadenti A, et al. Hydroxychloroquine with or without azithromycin in mild-to-moderate Covid-19. New England J Medicine. 2020. https://doi.org/10.1056/NEJMoa2019014

79. Borba MGS, Almeida FF, Sampaio VS, Alexandre MAA, Melo GC, Brito M, Mourao MPG, et al. Effect of High vs LowDoses of Chloroquine Diphosphate as Adjunctive Therapy for Patients Hospitalized With Severe Acute Respiratory Syndrome Coronavirus 2 (SARS-CoV-2) Infection A Randomized Clinical Trial. JAMA. 2020;3(4.23): e208857. doi:https://doi.org/10.1001/ jamanetworkopen.2020.8857.

80. Boulware DR, Pullen MF, Bangdiwala AS, Pastick KA, Lofgren SM, Okafor EC, Skipper CP, et al. A randomized trial of Hydroxychloroquine as Postexposure prophylaxis for Covid-19. N Engl J Med. 2020;383:517-25.

81. Magagnoli J, Narendran S, Pereira F, Cummings T, Hardin JW, Sutton SS, Ambati Outcomes of hydroxychloroquine usage in United States veterans hospitalized with Covid-19. Med. 2020. https://doi.org/10.1016/j.medj.2020.06.001.

\section{Publisher's Note}

Springer Nature remains neutral with regard to jurisdictional claims in published maps and institutional affiliations.

Ready to submit your research? Choose BMC and benefit from:

- fast, convenient online submission

- thorough peer review by experienced researchers in your field

- rapid publication on acceptance

- support for research data, including large and complex data types

- gold Open Access which fosters wider collaboration and increased citations

- maximum visibility for your research: over $100 \mathrm{M}$ website views per year

At BMC, research is always in progress.

Learn more biomedcentral.com/submission 